\title{
TRANSPORT REACTOR DEVELOPMENT UNIT MODIFICATION TO PROVIDE A SYNGAS SLIPSTREAM AT ELEVATED CONDITIONS TO ENABLE SEPARATION OF 100 LB/D OF HYDROGEN BY HYDROGEN SEPARATION MEMBRANES
}

Year 6 - Activity 1.15 - Development of a National Center for Hydrogen Technology

Topical Report

Prepared for:

AAD Document ControI

National Energy Technology Laboratory

U.S. Department of Energy

626 Cochrans Mill Road

PO Box 10940, MS 921-107

Pittsburgh, PA 15236-0940

DOE NETL Cooperative Agreement No. DE-FE0003466

Performance Monitor: Darryl Shockley

Prepared by:

Steven M. Schlasner

Energy \& Environmental Research Center

University of North Dakota 15 North 23rd Street, Stop 9018

Grand Forks, ND 58202-9018 


\section{EERC DISCLAIMER}

LEGAL NOTICE This research report was prepared by the Energy \& Environmental Research Center (EERC), an agency of the University of North Dakota, as an account of work sponsored by the U.S. Department of Energy (DOE) National Energy Technology Laboratory (NETL), the North Dakota Industrial Commission, and a consortium of industrial sponsors. Because of the research nature of the work performed, neither the EERC nor any of its employees makes any warranty, express or implied, or assumes any legal liability or responsibility for the accuracy, completeness, or usefulness of any information, apparatus, product, or process disclosed or represents that its use would not infringe upon privately owned rights. Reference herein to any specific commercial product, process, or service by trade name, trademark, manufacturer, or otherwise does not necessarily constitute or imply its endorsement or recommendation by the EERC.

\section{DOE ACKNOWLEDGMENT}

This report was prepared with the support of DOE NETL Cooperative Agreement No. DEFE0003466. However, any opinions, findings, conclusions, or recommendations expressed herein are those of the author(s) and do not necessarily reflect the views of DOE.

\section{DOE DISCLAIMER}

This report was prepared as an account of work sponsored by an agency of the United States Government. Neither the United States Government, nor any agency thereof, nor any of their employees makes any warranty, express or implied, or assumes any legal liability or responsibility for the accuracy, completeness, or usefulness of any information, apparatus, product, or process disclosed, or represents that its use would not infringe upon privately owned rights. Reference herein to any specific commercial product, process, or service by trade name, trademark, manufacturer, or otherwise does not necessarily constitute or imply its endorsement, recommendation, or favoring by the United States Government or any agency thereof. The views and opinions of authors expressed herein do not necessarily state or reflect those of the United States Government or any agency thereof. 


\title{
TRANSPORT REACTOR DEVELOPMENT UNIT MODIFICATION TO PROVIDE A SYNGAS SLIPSTREAM AT ELEVATED CONDITIONS TO ENABLE SEPARATION OF 100 LB/D OF HYDROGEN BY HYDROGEN SEPARATION MEMBRANES
}

\author{
Year 6 - Activity 1.15 - Development of a National \\ Center for Hydrogen Technology
}

\begin{abstract}
Gasification of coal when associated with carbon dioxide capture and sequestration has the potential to provide low-cost as well as low-carbon hydrogen for electric power, fuels or chemicals production. The key element to the success of this concept is inexpensive, effective separation of hydrogen from carbon dioxide in synthesis gas. Many studies indicate that membrane technology is one of the most, if not the most, economical means of accomplishing separation; however, the advancement of hydrogen separation membrane technology is hampered by the absence of experience or demonstration that the technology is effective economically and environmentally at larger scales. While encouraging performance has been observed at bench scale (less than $12 \mathrm{lb} / \mathrm{d}$ hydrogen), it would be imprudent to pursue a largescale demonstration without testing at least one intermediate scale, such as $100 \mathrm{lb} / \mathrm{d}$ hydrogen. Among its many gasifiers, the Energy \& Environmental Research Center is home to the transport reactor demonstration unit (TRDU), a unit capable of firing $200-500 \mathrm{lb} / \mathrm{hr}$ of coal to produce $400 \mathrm{scfm}$ of synthesis gas containing more than $200 \mathrm{lb} / \mathrm{d}$ of hydrogen. The TRDU and associated downstream processing equipment has demonstrated the capability of producing a syngas over a wide range of temperatures and contaminant levels - some of which approximate conditions of commercial-scale gasifiers. Until this activity, however, the maximum pressure of the TRDU's product syngas was $120 \mathrm{psig}$, well below the $400+$ psig pressures of existing large gasifiers. This activity installed a high-temperature compressor capable of accepting the range of TRDU products up to $450^{\circ} \mathrm{F}$ and compressing them to $500 \mathrm{psig}$, a pressure comparable to some largescale gasifiers. Thus, with heating or cooling downstream of the TRDU compressor, the unit is now able to present a near-raw to clean gasifier synthesis gas containing more than $100 \mathrm{lb} / \mathrm{d}$ of hydrogen at up to $500 \mathrm{psig}$ over a wide range of temperatures to hydrogen separation membranes or other equipment for development and demonstration.
\end{abstract}




\section{TABLE OF CONTENTS}

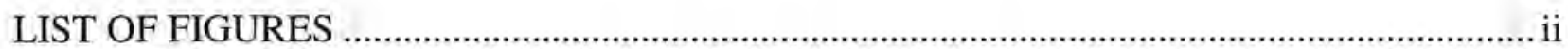

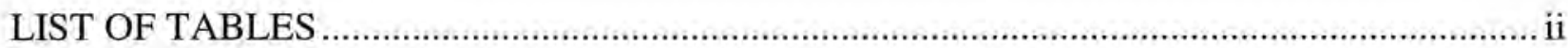

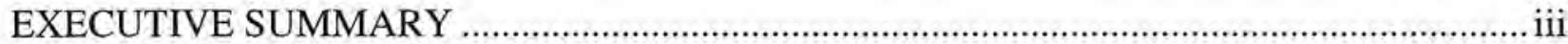

APPROACH

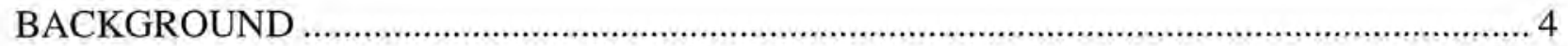

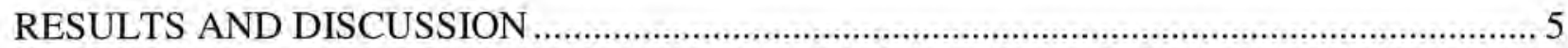

Task 1 - Design and Procurement and Task 2 - Installation and Testing ......................... 5

Task 3 - Management and Reporting …........................................................................ 7

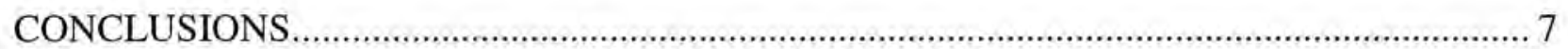

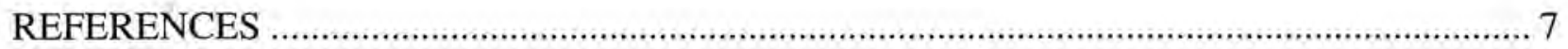

TRANSPORT REACTOR DEVELOPMENT UNIT (TRDU) ...................................ppendix A 


\section{LIST OF FIGURES}

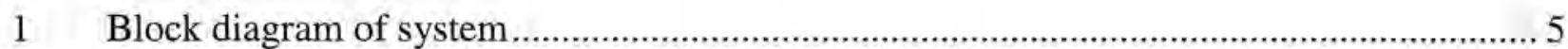

\section{LIST OF TABLES}

1 Gasifier Synthesis Gas Conditions Upstream of Shift Reactors ..................................... 3

2 Range of Gasifier Compositions Upstream of Shift Reactors ............................................. 3

3 Gasifier Synthesis Gas Conditions Downstream of Shift Reactors ................................. 4 


\title{
TRANSPORT REACTOR DEVELOPMENT UNIT MODIFICATION TO PROVIDE A SYNGAS SLIPSTREAM AT ELEVATED CONDITIONS TO ENABLE SEPARATION OF 100 LB/D OF HYDROGEN BY HYDROGEN SEPARATION MEMBRANES
}

\author{
Year 6 - Activity 1.15 - Development of a National \\ Center for Hydrogen Technology
}

\section{EXECUTIVE SUMMARY}

Precombustion technologies, i.e., technologies that produce synthesis gas from fossil fuels and then separate and sequester the carbon dioxide prior to using the hydrogen for producing electricity or as fuel or chemical feedstock, have great potential to produce low-carbon energy or chemicals. The goal of the U.S. Department of Energy's Hydrogen from Coal Program is to demonstrate cost-effective, low-carbon, stationary electric power generation based upon hydrogen separation and carbon capture from coal-based synthesis gas. A critical, high-potential component of this concept is hydrogen separation membrane technology; however, the advancement of the technology is hampered by the absence of experience or demonstration that the technology is effective economically and environmentally at larger scales. Laboratory-scale production of up to 12 pounds of hydrogen a day have been encouraging, but insufficient to justify full-scale demonstration. The Energy \& Environmental Research Center (EERC) operates a transport reactor development unit (TRDU) gasifier capable of providing a synthesis gas slipstream containing more than $100 \mathrm{lb} / \mathrm{d}$ of hydrogen over a wide range of temperatures and contaminant levels, some of which approximates conditions of commercial-scale gasifers. This volume-intermediate between bench and full scale-is at a scale that is suitable to provide assurance of the efficacy of the separation technology at reasonable cost. Unfortunately, the TRDU's syngas-product pressure is only $120 \mathrm{psig}$, which is significantly less than the $400+$ psig operating pressure of existing large gasifiers. To remedy this deficiency, a project has been completed to add a compressor capable of providing a high-temperature, 500 psig syngas slipstream containing more than $100 \mathrm{lb} / \mathrm{d}$ hydrogen suitable for hydrogen separation membrane testing. The system is capable of providing a very clean (low contaminant) syngas stream at low or high temperatures or a near-raw syngas at low or high temperature (where the level of contaminants is determined by condensation occurring at the minimum downstream temperature which, for high-temperature tests, would be $450^{\circ} \mathrm{F}$ : the compressor's maximum allowed suction temperature). Final gas stream temperature at the membrane can be adjusted by heating or cooling between the compressor and the membrane. 


\title{
TRANSPORT REACTOR DEVELOPMENT UNIT MODIFICATION TO PROVIDE A SYNGAS SLIPSTREAM AT ELEVATED CONDITIONS TO ENABLE SEPARATION OF 100 LB/D OF HYDROGEN BY HYDROGEN SEPARATION MEMBRANES
}

\author{
Year 6 - Activity 1.15 - Development of a National Center for Hydrogen Technology
}

\section{APPROACH}

Hydrogen is a key feedstock and chemical component for many industrial processes, such as:

- Ammonia Production - Industrial ammonia production involves reaction of hydrogen, typically derived from natural gas, with nitrogen by means of the Haber process. Ammonia is used in fertilizer manufacture, industrial refrigeration systems, and the manufacture of a variety of industrial chemicals. Hydrogen production for ammonia in the United States is strongly influenced by the price of natural gas feedstock which rose then fell from about $\$ 3$ per thousand cubic feet in October 2001 to more than $\$ 13$ per thousand cubic feet in July 2008 to $\$ 4.50$ per thousand cubic feet in November 2011. U.S. production of ammonia followed ammonia's price by declining during the period 2000-2006 and stabilizing during 2007-2010.

- Petroleum Refining - In petroleum refineries, hydrogen is used to upgrade viscous oil fractions to produce products such as gasoline and diesel and for removing contaminants such as sulfur. Demand for hydrogen in refineries has increased 1) as more and heavier, hydrogen-deficient crude oils have been processed, 2) as fuel standards have become more stringent, and 3 ) as sulfur content has become more tightly regulated.

- Chemicals - Hydrogen is used as a raw material in the chemical synthesis of hydrogen peroxide, polymers, and solvents. Hydrogen is also used to purify gases (e.g., argon) that contain trace amounts of oxygen, using catalytic combination of the oxygen and hydrogen followed by removal of the resulting water.

- Pharmaceuticals - The pharmaceutical industry uses hydrogen to manufacture vitamins and other pharmaceutical products.

- Food and Beverages - Hydrogen is used to hydrogenate unsaturated fatty acids in animal and vegetable oils, producing solid fats for margarine and other food products.

- Semiconductor Manufacture - The semiconductor industry uses hydrogen to stabilize amorphous silicon and carbon materials.

- Miscellaneous - Generators in large power plants are often cooled with hydrogen, since the gas possesses high thermal conductivity and offers low friction resistance. The 
nuclear fuel industry also uses hydrogen as a protective atmosphere in the fabrication of fuel rods.

Prior to the recession of 2009, global hydrogen production was estimated to be 41-65 million metric tonnes a year and was expanding with general economic activity and refining of increasing volumes of heavier crude oils. The $9 \%$ decline in global industrial production during 2009 produced a contraction in hydrogen production, which, since, has been reversed to the extent that hydrogen demand is forecast to grow about $3.5 \%$ annually through 2013, with Asia/Pacific countries growing faster than other regions of the world. Demand growth, increased energy costs, and new environmental regulations will likely drive hydrogen producers to install new production technologies and modify existing facilities to increase production capacity, achieve improved efficiencies, and reduce emission levels to ensure their competitiveness and compliance.

Longer-term forecast of hydrogen demand is uncertain, but, as in the recent past, will likely be influenced heavily by environmental concerns. Climate change issues, for example, are prompting a call to reduce petroleum-based liquid fuels by substituting battery technologies, biobased liquid fuels, hydrogen fuel cells, or other technologies. These alternatives vary in their hydrogen requirements from almost none in the case of some batteries to extreme for hydrogen fuel cells. Interestingly, biodiesel production could create a surprisingly significant demand for hydrogen. Bio-oil feedstocks contain significant amounts of oxygen and varying levels of unsaturation which contribute to fuel quality, oxidative stability, $\mathrm{NO}_{\mathrm{x}}$ emissions, and other issues. Hydrogenation offers a solution to these issues and improved compatibility among petroleum- and bio-oil-based fuels. As a result, reduction in petroleum consumption will not automatically eliminate hydrogen demand. The direction of future hydrogen production, however, will be toward cheaper, lower-carbon-emission hydrogen-a situation that some studies assert is provided best by separation of hydrogen from a cheap carbonaceous-based shifted syngas by membranes from which the by-product carbon dioxide is sequestered.

Longer-term, hydrogen also is an appealing fuel for stationary power production at both large centralized and smaller distributed scales. Currently, hydrogen fuel cell use for backup power generation is expanding in distributed applications such as communication systems, in which small (i.e., less than $5 \mathrm{~kW}$ ) power sources are required. In the future, coal gasification and natural gas reforming when coupled with hydrogen separation and carbon sequestration technologies could provide a less expensive approach to generate large volumes of low-carbon hydrogen for such purposes as electric power generation than is available using current technologies. U.S. Department of Energy (DOE) documents acknowledge the potential of hydrogen to reduce costs, improve efficiency, and reduce the complexity of coal-based clean electric power.

The DOE study, Current and Future Technologies for Gasification-Based Power Generation: Volume 2 (1), indicates that hydrogen separation membranes offer the greatest efficiency improvement and cost savings of any single, alternative carbon capture technology employed in conjunction with integrated gasification combined-cycle technology. Another DOE document, Hydrogen from Coal Program: Securing Our Future Multi-Year Research, Development and Demonstration (RD\&D) Plan for the period 2010 through 2016 (2), however, 
enumerates 17 technical barriers that must be resolved before clean electric power from coal can become a reality. One of these barriers is the "lack of demonstration of novel technologies. . at a scale sufficient to determine their potential for lower cost and efficient integration into advanced hydrogen from coal production systems." The RD\&D Plan specifically refers to advanced membranes as possessing this deficiency. The NETL Test Protocol: Testing of Hydrogen Separation Membranes (3) addresses this barrier by establishing a series of test phases that subject membranes to progressively more rigorous (i.e., more realistic) conditions, which include exposure to partially cleaned or raw syngas at 500-800 psi - "exposure to actual gasifier raw gas is desirable." Ultimately, the RD\&D Plan states that an advanced hydrogen separation membrane, in conjunction with warm-gas cleanup and an advanced turbine, provides the best alternative of those studied. The goal of the project described herein is to provide capability for an existing gasifier to produce a range of conditions, some of which approximate commercialscale units, at synthesis gas feed rates containing more than 100 pounds of hydrogen a day (45.4 scfm hydrogen) suitable for delivery to a hydrogen separation membrane for testing.

A table in the DOE document, NETL Test Protocol: Testing of Hydrogen Separation Membranes (3), that describes operating conditions of several existing commercial gasifier designs provided the basis for the project's target operating conditions. Following are excerpts from that table (Tables $1-3$ ):

Table 1. Gasifier Synthesis Gas Conditions Upstream of Shift Reactors (3)

\begin{tabular}{lcccc}
\hline $\begin{array}{l}\text { Vendor Condition } \\
\text { Gasifier }\end{array}$ & $\begin{array}{c}\text { GE Energy } \\
\text { Radiant }\end{array}$ & $\begin{array}{c}\text { ConocoPhillips } \\
\text { E-Gas }\end{array}$ & $\begin{array}{c}\text { KBR } \\
\text { Transport Integrated } \\
\text { Gasifier (TRIG) }\end{array}$ & Shell \\
\hline Pressure, psia & 800 & 614 & $400+$ & 565 \\
Temperature, ${ }^{\circ} \mathrm{F}$ & 410 & 1700 & $500-700$ & 500 \\
\hline
\end{tabular}

Table 2. Range of Gasifier Compositions Upstream of Shift Reactors (3)

\begin{tabular}{lc}
\hline Component & Mole Percentage \\
\hline $\mathrm{H}_{2}$ & $15.6-29.2$ \\
$\mathrm{CO}$ & $26.7-37$ \\
$\mathrm{CO}_{2}$ & $1.13-14$ \\
$\mathrm{H}_{2} \mathrm{O}$ & $15-48.3$ \\
$\mathrm{CH}_{4}$ & $0.02-4$ \\
$\mathrm{H}_{2} \mathrm{~S}$ & $0.056-0.56$ \\
$\mathrm{COS}$ & $0.0-0.04$ \\
$\mathrm{NH}_{3}$ & $0.13-0.28$ \\
$\mathrm{HCN}$ & 0.032 \\
\hline
\end{tabular}


Table 3. Gasifier Synthesis Gas Conditions Downstream of Shift Reactors (3)

\begin{tabular}{lccc}
\hline & GE Energy & ConocoPhillips & \\
Vendor Condition Gasifier & Radiant & E-Gas & Shell \\
\hline Pressure, psia & 777 & 516 & 483 \\
Temperature, ${ }^{\circ} \mathrm{F}$ & 519 & 457 & 95 \\
\hline
\end{tabular}

\section{BACKGROUND}

The Energy \& Environmental Research Center (EERC) has performed research into coal gasification for more than 60 years and, today, possesses one of the largest single-site collections of pilot-scale gasifiers in the world. One of these systems, the transport reactor demonstration unit (TRDU), is capable of firing $200-500 \mathrm{lb}$ an hour of fuel to produce about $400 \mathrm{scfm}$ of synthesis gas that contains substantially more than $200 \mathrm{lb}$ per day of hydrogen. A detailed description of the equipment can be found in Appendix A. Equipment downstream of the gasifier can be configured to provide various extents of cleanup from extensive cleanup to produce a clean syngas stream to minimal cleanup to produce raw syngas. Capabilities also exist to incorporate water-gas shift to increase the hydrogen content in the syngas and to adjust the temperature of the stream to better reflect product syngas streams of commercial-scale gasification systems. At the clean extreme, previous tests have shown that the cleanup train can reduce sulfur compounds to $0.01 \mathrm{ppm}$ or less, shift CO content to less than $1 \mathrm{vol} \%$, eliminate $\mathrm{HCl}$, and maximize $\mathrm{H}_{2}$-all while maintaining the temperature of the syngas above $450^{\circ} \mathrm{F}$. From the product stream, then, a slipstream may be withdrawn for tasks such as testing hydrogen separation membranes, which has been accomplished by the TRDU in the past.

Prior to the project reported herein, tests using a slipstream from the TRDU produced an ultrapure stream of hydrogen from a Texas lignite while maintaining the gas temperature above $400^{\circ} \mathrm{F}$. The slipstream was cleaned and conditioned by running through a transport-style desulfurizer for bulk desulfurization, a high-temperature shift catalyst, a sulfur polishing bed, a chlorine guard bed, a low-temperature shift catalyst, and a mercury control sorbent. The cleaned syngas then was directed to a hydrogen separation membrane to demonstrate the membrane's ability to produce separate streams of pure hydrogen and concentrated carbon dioxide.

It is the goal of the project described herein to provide the TRDU with capability to produce a slipstream of synthesis gas at a range of conditions, some of which approximate commercial-scale units, and at feed rates of more than $100 \mathrm{lb} / \mathrm{d}$ hydrogen for durations of up to 8 hours which is suitable for hydrogen separation membrane testing.

While capable of generating a slipstream that would expose test membranes to a range of conditions, the TRDU has a maximum operating pressure of 120 psig, which is substantially less than the desired 400+ psi pressures of gasifiers described in the NETL Test Protocol: Testing of Hydrogen Separation Membranes (Tables 1 and 3) (3). To address this limitation, the project reported herein modified the TRDU downstream equipment to include a compressor capable of providing a stream of about $250 \mathrm{scfm}$ at more than $500 \mathrm{psig}$ for periods of more than 8 hours, Of this stream, more than $45 \mathrm{scfm}$ can be sent to the membrane for separation to produce $100 \mathrm{lb} / \mathrm{d}$ of 
hydrogen with the remainder returned to the gasifier to satisfy purge requirements. Figure 1 displays a block diagram of system modifications. While the modified system does not attain the harshest conditions projected by DOE for future commercial gasifiers (such as $800+$ psi syngas product pressure), its 500 psia design pressure places it in the range of existing gasifiers (Tables 1 and 3). It should be noted, though, that the compressor can be modified to achieve $800+$ psi exhaust pressure merely by the addition of a single stage, if such pressures are desired in the future.

Ultimately, the modified TRDU system can perform cold- or warm-gas (up to $450^{\circ} \mathrm{F}$ ) cleanup, with or without water-gas shift to produce a synthesis gas product stream of more than $45 \mathrm{scfm}$ containing more than $100 \mathrm{lb} / \mathrm{d}$ of hydrogen, at pressures up to $500 \mathrm{psig}$.

This project does not test hydrogen separation membranes; consequently, it does not provide complete facilities for testing which include permeate and retentate collection lines, flowmeters and gas analyzer, and means to introduce sweep gas to the permeate. These are expected to be added in subsequent projects.

\section{RESULTS AND DISCUSSION}

The project's work plan comprised six tasks (i.e., system design, procurement, installation, and testing, as well as management and reporting), which have been paired into three major tasks as indicated below.

\section{Task 1 - Design and Procurement and Task 2 - Installation and Testing}

The design subtask reviewed the layout and mechanical diagrams of the existing TRDU and associated equipment to identify tie-in points, location of membrane test articles, pipe routings, utility locations and line routings, as well as compressor utility and siting requirements. A preliminary siting review during proposal preparation concluded that locating the compressor

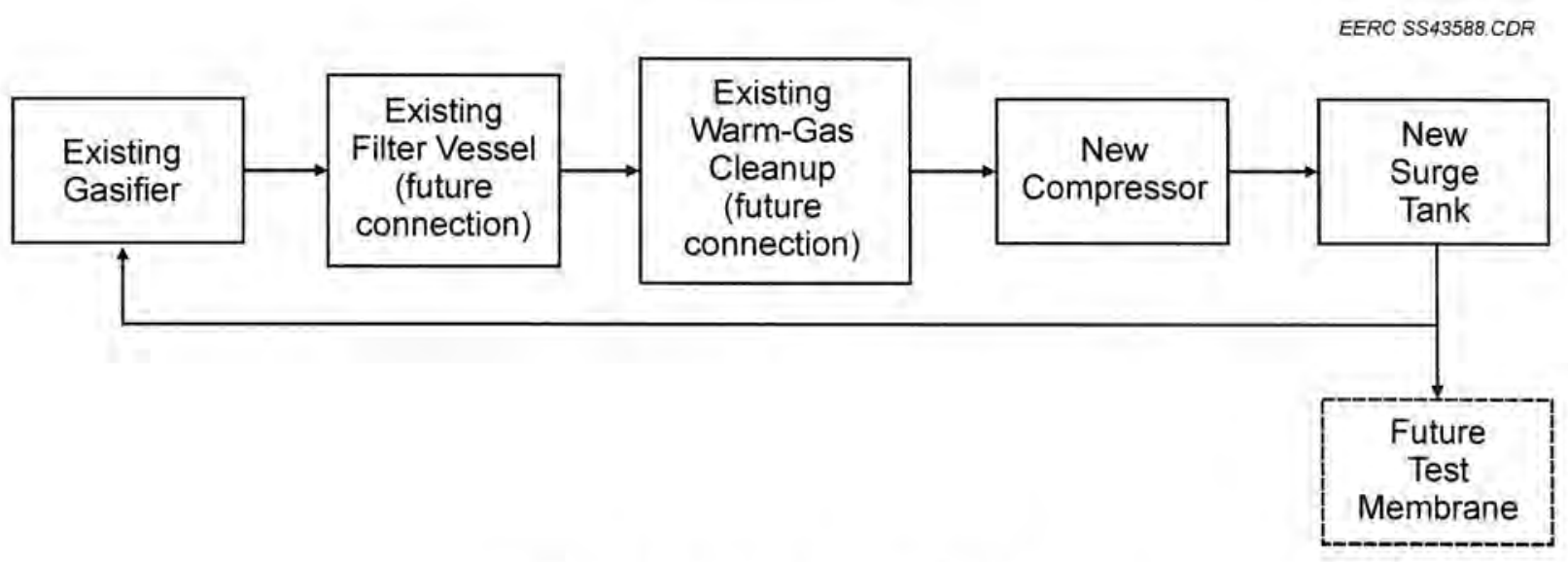

Figure 1. Block diagram of system. 
in an enclosure immediately adjacent to the building housing the TRDU would provide the best access and support for the compressor and associated equipment; however, a more suitable space inside the building housing the TRDU was identified shortly after the proposal was submitted which had better access, was more controlled, and required less site preparation, so it was selected to house the compressor.

A compressor specification was prepared, and several compressor vendors were contacted to obtain budgetary cost estimates prior to proposal submission. Unexpectedly, only two vendors (Sundyne Corporate and RIX Industries) expressed interest and demonstrated experience in manufacturing high-temperature compressors of the size required for this project. Although Sundyne manufactures compressors capable of operating at elevated temperatures, the model that most closely matched this project's specification was substantially larger than the unit specified. Despite the lack of interest or experience, once the project was approved, the EERC submitted requests for quotes from five vendors, including RIX Industries, IMW Industries Ltd., Pressure Products Industries - Milton Roy, PDC, and Sundyne Corporation. Requests did not go to GE and FS Elliot, which had been contacted previously. Only RIX Industries responded with a quote, and thus, consequently, received the purchase order.

A hazard and operability (HAZOP) review was performed to identify potential safety issues with installation and operation of the compressor and associate equipment. Twenty-four action items were identified; all items have been resolved. An environmental review indicated no change to existing permits was required. Other internal reviews and approvals were routine and without issue.

Concerns by TRDU operating engineers regarding compressor interstage cooling resulted in changing cooling medium from ambient-temperature water to hot water, which added a pressurized cooling loop. The compressor manufacturer approved the modification without modifying compressor heat exchangers, due to the fact that the exchangers originally had been overdesigned. Fabrication of the secondary heat exchanger was performed in EERC's machine shop.

The remaining major equipment item, the high-temperature surge tank, was fabricated by an outside shop, VAL-FAB Inc. The vessel was placed into the TRDU building, and the associated valves and piping were installed.

As a cost-control measure and to provide consistency with other EERC controllers, the compressor was purchased without control panel, motor starter, and instrumentation. These were acquired, programmed, and installed internally by EERC engineers and technicians.

Another cost-control measure was to install a few existing valves that had been "surplused" from the TRDU.

Electrical, mechanical, and control installation were followed by successful completion of pressure and site acceptance testing on nitrogen. 
Since the goal of the project described herein was to provide capability and verify operation, no experimentation was conducted, and no research data was generated. Engineering data acquired by this project were limited to design information and operational test results. The compressor was successfully operated on nitrogen to demonstrate electrical and mechanical connectivity and programming functionality. Vendor and design documentation has been collected and archived, as well as programming documentation, operating procedures, findings and recommendations of the HAZOP review, and other documentation. Final connections and installation of test membranes will be performed as part of subsequent membrane test projects.

\section{Task 3 - Management and Reporting}

As proposed, quarterly progress reports have been submitted DOE, and this report confirms completion of installation and successful testing of the compressor.

\section{CONCLUSIONS}

The TRDU and associated downstream processing equipment are capable of delivering more than $100 \mathrm{lb} / \mathrm{d}$ of hydrogen in a coal-based synthesis gas stream under a wide range of conditions, many of which approximate commercial-scale gasifier syngas product streams. Until this project, however, the unit was unable to supply syngas at pressures comparable to commercial-scale gasifiers. This project has expanded the TRDU's capability to enable it to produce a 500 psig slipstream suitable for hydrogen separation membrane performance evaluation or other purposes. An unexpected discovery was the difficulty in identifying and receiving quotes from compressor vendors that possessed demonstrated experience in manufacturing high-temperature compressors of the size required for this project.

\section{REFERENCES}

1. U.S. Department of Energy, Fossil Energy, National Energy Technology Laboratory. Current and Future Technologies for Gasification-Based Power Generation Volume 2: A Pathway Study Focused on Carbon Capture Advanced Power Systems R\&D Using Bituminous Coal, Revision 1; DOE/NETL-2009/1389, Nov 2010.

2. U.S. Department of Energy, Fossil Energy, National Energy Technology Laboratory. Hydrogen from Coal Program: Securing Our Future, Research, Development and Demonstration (RD\&D) Plan for the Period 2010 through 2016; External Draft, Sept 2010.

3. U.S. Department of Energy, Fossil Energy, National Energy Technology Laboratory. NETL Test Protocol: Testing of Hydrogen Separation Membranes; DOE/NETL-2008/1335, Oct 2008. 
APPENDIX A

\section{TRANSPORT REACTOR DEVELOPMENT UNIT}

(TRDU) 


\section{TRANSPORT REACTOR DEVELOPMENT UNIT (TRDU)}

The transport reactor development unit (TRDU) was originally built for KBR and Southern Company through a U.S. Department of Energy (DOE) project and is the pilot-scale version of the power systems demonstration facility (PSDF) in Wilsonville, Alabama. The TRDU is equipped with a hot-gas filter vessel for particulate removal and a thermal oxidizer to convert the combustibles and tars before venting to the stack. A slipstream can be pulled from the system between the hot-gas filter vessel and the thermal oxidizer that can be used for testing gas cleanup and separation technologies.

The pilot-scale TRDU has an exit gas temperature of up to $980^{\circ} \mathrm{C}\left(1800^{\circ} \mathrm{F}\right)$, a gas flow rate of $400 \mathrm{scfm}\left(0.153 \mathrm{~m}^{3} / \mathrm{s}\right)$, and an operating pressure of $120 \mathrm{psig}(9.3 \mathrm{bar})$. The TRDU system can be divided into three sections: the coal feed section, the TRDU, and the product recovery section. The TRDU proper, as shown in Figure A-1, consists of a riser reactor with an expanded mixing zone at the bottom, a disengager, and a primary cyclone and standpipe. The standpipe is connected to the mixing section of the riser by an L-valve transfer line. All of the components in the system are refractory-lined and designed mechanically for $150 \mathrm{psig}(11.4 \mathrm{bar})$ and an internal temperature of $1090^{\circ} \mathrm{C}\left(2000^{\circ} \mathrm{F}\right)$. Detailed design criteria and a comparison to actual operating conditions on the design coal are given in Table A-1.

The premixed coal and limestone feed to the transport reactor can be admitted through three nozzles, which are at varying elevations. Two of these nozzles are located near the top of the mixing zone (gasification), and the remaining one is near the bottom of the mixing zone (combustion). During operation of the TRDU, feed is admitted through only one nozzle at a time.

The coal feed is measured by an rpm-controlled metering auger. Oxidant is fed to the reactor through two pairs of nozzles at varying elevations within the mixing zone. For the combustion mode of operation, additional nozzles are provided in the riser for feeding secondary air. Hot solids from the standpipe are circulated into the mixing zone, where they come into contact with the nitrogen and the steam being injected into the L-valve. This feature enables spent char to contact steam prior to the fresh coal feed. This staged gasification process is expected to enhance process efficiency. Gasification or combustion and desulfurization reactions are carried out in the riser as coal, sorbent, and oxidant (with steam for gasification) flow up the reactor. The solids circulation into the mixing zone is controlled by fluffing gas in the standpipe, J-leg aeration flows, and the solids level in the standpipe.

The riser, disengager, standpipe, and cyclones are equipped with several internal and skin thermocouples. Nitrogen-purged pressure taps are also provided to record differential pressure across the riser, disengager, and cyclones. The data acquisition and control system scans the data points every $1 / 2$ second and is saving the process data every $30 \mathrm{~s}$. The bulk of entrained solids leaving the riser is separated from the gas stream in the disengager and circulated back to the riser via the standpipe. A solids stream is withdrawn from the standpipe via an auger to maintain the system's solids inventory. Gas exiting the disengager enters a primary cyclone. The dipleg solids have been recirculated back to the standpipe through a loop seal at the bottom of the 


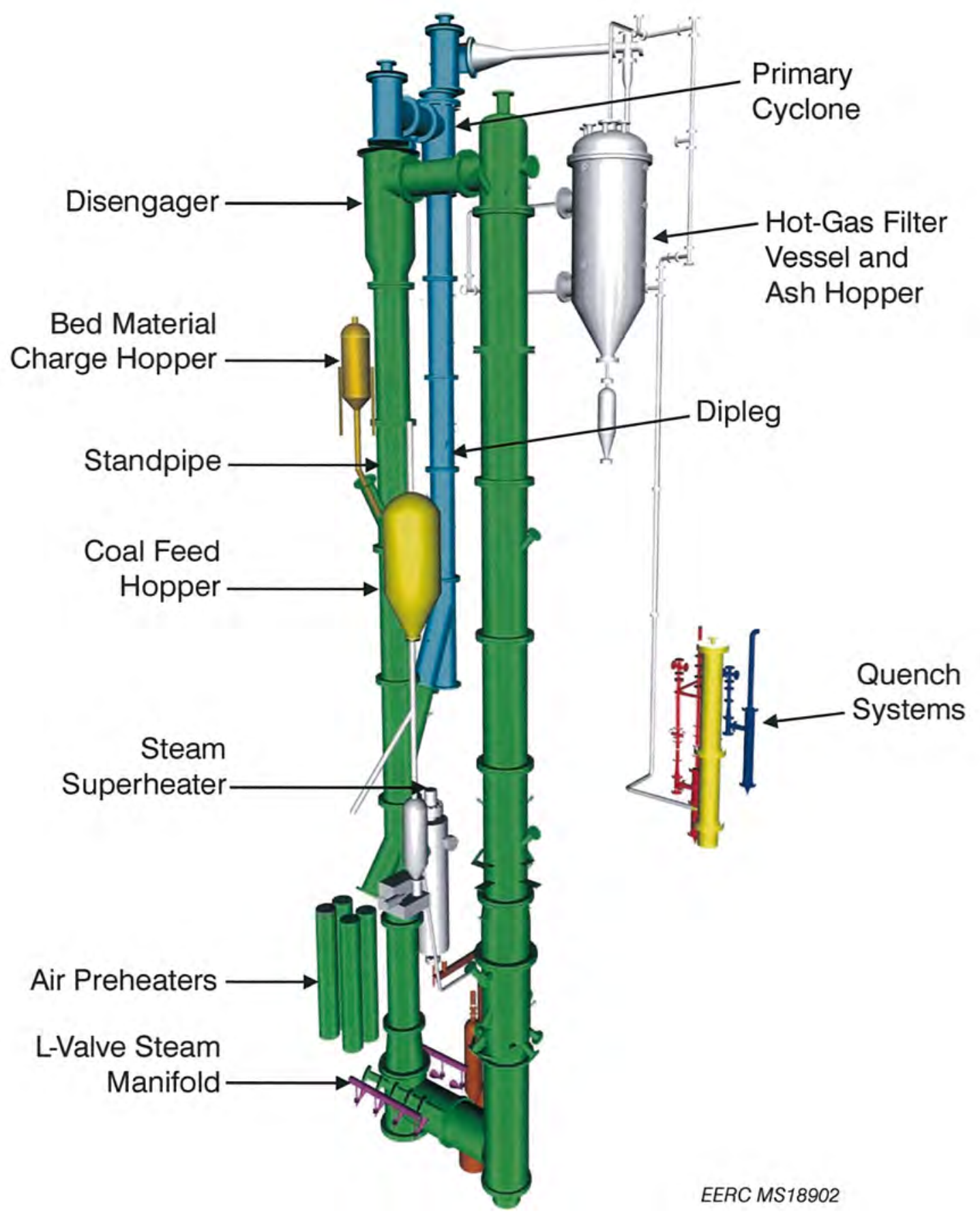

Figure A-1. Schematic of the TRDU. 
Table A-1. Summary of TRDU Design and Operation on the Design Coal Parameter

\begin{tabular}{|c|c|c|}
\hline & Design & Actual \\
\hline Coal & Illinois No, 6 & Illinois No. 6 \\
\hline Moisture Content, $\%$ & 5 & 8.5 \\
\hline Pressure, psig & 120 (9.3 bar) & 120 (9.3 bar) \\
\hline Steam/Coal Ratio & 0.34 & 0.34 \\
\hline Air/Coal Ratio & 4.0 & 2.3 \\
\hline $\mathrm{Ca} / \mathrm{S}$ Ratio, mol & 1.5 & 2.0 \\
\hline Air Inlet Temperature, ${ }^{\circ} \mathrm{C}$ & 427 & 180 \\
\hline Steam Preheat, ${ }^{\circ} \mathrm{C}$ & 537 & 350 \\
\hline Coal Feed Rate, lb/hr & $198(89.9 \mathrm{~kg} / \mathrm{hr})$ & $220(99.9 \mathrm{~kg} / \mathrm{hr})$ \\
\hline Gasifier Temperature, maximum ${ }^{\circ} \mathrm{C}$ & 1010 & 950 \\
\hline Maximum Temp., ${ }^{\circ} \mathrm{C}$ & 17 & 60 to 100 \\
\hline Carbon Conversion, ${ }^{1} \%$ & $>80$ & 76.5 \\
\hline $\mathrm{HHV}^{2}$ of Fuel Gas, Btu/scf & 100 & 110 \\
\hline Heat Loss as Coal Feed, $\%$ & 19.5 & 13 \\
\hline Riser Velocity, ft/sec & 31.3 & 25 \\
\hline Heat Loss, Btu/hr & 252,000 & 320,000 \\
\hline Standpipe Superficial Velocity, $\mathrm{ft} / \mathrm{sec}$ & 0.1 & 0.38 \\
\hline
\end{tabular}

${ }^{1}$ Carbon conversion $=(w t$ carbon feed $-w t$ carbon removed $) / w t$ carbon feed $* 100$.

${ }^{2}$ Higher heating value.

dipleg. Gas exiting this cyclone enters a jacketed-pipe heat exchanger before entering the hot-gas filter vessel (HGFV). The warm particulate-free gases leaving the HGFV are vented directly into a thermal oxidizer where they are combusted.

\section{Hot-Gas Filter Vessel}

This vessel is designed to handle all of the gas flow from the TRDU at its expected operating conditions. The vessel is approximately 48 -in. $(121.9-\mathrm{cm})$ inside diameter (i.d.) and 185 in. $(470 \mathrm{~cm})$ long and is designed to handle gas flows of approximately $325 \mathrm{scfm}$ at temperatures up to $815^{\circ} \mathrm{C}\left(1500^{\circ} \mathrm{F}\right)$ and $120 \mathrm{psig}(8.3 \mathrm{bar})$. The refractory has a 28 -in. $(71.1-\mathrm{cm})$ i.d. with a shroud diameter of approximately $22 \mathrm{in} .(55.9 \mathrm{~cm})$. The vessel is sized such that it could handle candle filters up to $1.5 \mathrm{~m}$ long; however, $1-\mathrm{m}$ candles were utilized in the $540^{\circ} \mathrm{C}$ $\left(1000^{\circ} \mathrm{F}\right)$ gasification tests to date. Candle filters are 2.375-in. $(6-\mathrm{cm})$ outside diameter with 4-in. $(10.2-\mathrm{cm})$ center line-to-center line spacing. The filter design criteria are summarized in Table A-2.

The total number of candles that can be mounted in the current geometry of the HGFV tube sheet is 19. This enables filter face velocities as low as $2.0 \mathrm{ft} / \mathrm{min}$ to be tested using $1.5-\mathrm{m}$ candles. Higher face velocities are achieved by using fewer candles. The majority of testing has been performed at a face velocity of approximately 4.0 to $4.5 \mathrm{ft} / \mathrm{min}$. This program has tested an Industrial Filter \& Pump ceramic tube sheet and Fibrosic and REECER SiC candles, and silicon 
Table A-2. Design Criteria and Actual Operating Conditions for the Pilot-Scale HGFV

\begin{tabular}{lcc}
\hline Operating Conditions & Design & Actual \\
\hline Inlet Gas Temperature & $540^{\circ} \mathrm{C}$ & $450^{\circ}-580^{\circ} \mathrm{C}$ \\
Operating Pressure & $150 \mathrm{psig}(10.3 \mathrm{bar})$ & $120 \mathrm{psig}(8.3 \mathrm{bar})$ \\
Volumetric Gas Flow & $325 \mathrm{scfm}\left(0.153 \mathrm{~m}^{3} / \mathrm{s}\right)$ & $350 \mathrm{scfm}\left(0.165 \mathrm{~m}^{3} / \mathrm{s}\right)$ \\
Number of Candles & $19(1 \mathrm{or} 1.5 \mathrm{~meter})$ & $13(1 \mathrm{~meter})$ \\
Candle Spacing & $4 \mathrm{in} \Phi$ to $\Phi$ & $4 \mathrm{in} \Phi$ to $\Phi$ \\
& $(10.2 \mathrm{~cm})$ & $(10.2 \mathrm{~cm})$ \\
Filter Face Velocity & $2.5-10 \mathrm{ft} / \mathrm{min}$ & $4.5 \mathrm{ft} / \mathrm{min}$ \\
& $(1.3$ to $2.3 \mathrm{~cm} / \mathrm{s})$ & $(2.3 \mathrm{~cm} / \mathrm{s})$ \\
Particulate Loading & $<10,000 \mathrm{ppmw}$ & $<38,000 \mathrm{ppmw}$ \\
Temperature Drop Across HGFV & $<30^{\circ} \mathrm{C}$ & $25^{\circ} \mathrm{C}$ \\
Nitrogen Backpulse System Pressure & Up to $600 \mathrm{psig}(42 \mathrm{bar})$ & 250 to $350 \mathrm{psig}$ \\
& & $(17$ to $24 \mathrm{bar})$ \\
Backpulse Valve Open Duration & Up to $1 \mathrm{~s} \mathrm{duration}$ & $1 / 4 \mathrm{~s}$ duration \\
\hline
\end{tabular}

carbon-coated and $\mathrm{SiO}_{2}$ ceramic fiber candles from the $3 \mathrm{M}$ company, along with sintered metal (iron aluminide) and Vitropore silicon carbon ceramic candles from Pall Advanced Separation Systems Corporation. In addition, granular $\mathrm{SiC}$ candles from U.S. Filter/Schumacher and composite candle filters from McDermott Technologies and Honeywell were tested. Current testing has focused on Pall's iron aluminide metal filters. Also, candle filter fail-safes from Siemens-Westinghouse Science and Technology Center have been tested.

The ash letdown system consists of two sets of alternating high-temperature valves with a conical pressure vessel to act as a lock hopper. Additionally, a preheat natural gas burner attached to a lower inlet nozzle on the filter vessel can be used to preheat the filter vessel separately from the TRDU. The hot gas from the burner enters the vessel via a nozzle inlet separate from the dirty gas.

The high-pressure nitrogen backpulse system is capable of backpulsing up to four sets of four or five candle filters with ambient-temperature nitrogen in a time-controlled sequence. The pulse length and volume of nitrogen displaced into the filter vessel is controlled by regulating the pressure (up to $600 \mathrm{psig}$ [42 bar]) of the nitrogen reservoir and controlling the solenoid valve pulse duration. Figure A-1 also shows the filter vessel location and process piping in the Energy \& Environmental Research Center gasifier tower. A recently installed heat exchange surface now allows the hot-gas filter to operate in the $500^{\circ}$ to $1200^{\circ} \mathrm{F}$ range instead of the higher-temperature range of $800^{\circ}$ to $1000^{\circ} \mathrm{F}$ utilized in previous testing. This additional heat exchange surface was added to allow gas cooling to the temperature where $\mathrm{Hg}$ removal is likely to occur. Ports for obtaining hot high-pressure particulate and trace metal samples both upstream and downstream of the filter vessel were added to the filter system piping. 